given individually distinctive plastic leg bands. On the twenty-sixth day thoy travolled by air to Kahului, on Mqui,

The Slimbridge birds consisted of 10 juveniles, 7 one yoar old, 10 two yoars old, 2 three yoars old und 1 four years old. 17 were females and 13 males. At Kahului they wore joined by five juvenile fornales reared by the Stato's Pohakuloa propagation project on Hawaii. Tho 35 birds were put in light-weight cardboard boxes and taken by lorry up to the rim of Haloakala Crator. Horo the boxos wore loadod on pack boards and wore carried on the backs of 23 Boy Scout volunteers 8.5 miles down into tho Crator and across to the reloaso pon at Paliku on the other side.

'The release pen at Paliku encloses about an acre of good grass, on tho odgo of an ancient 'aa' lava flow. 'Tho goese were released in the late afternoon of July 26. As they woro romovod from tho boxes, their clipped primaries were extracted so that new feathers would start to grow immediately. The birds were given constant care and suppliod with native borries and serateh food daily. They were also troatiod for coccidiosis and oxcal worms-these parasites having been detected in the fæcal droppings of the flock. Thore was much pecking and other signs of social adjustment for a woek or so, but the birds soon sott'ed down.

The gooso began making short flights within the pen early in september. The first flights out of the pen wore soon on Soptomber 12, two Hawaiian-reared birds being the pioneers. The first Slimbridgo bird did not fly out until September 17. By the end of the month, 27 out of the 35 were flying a fow hundred yards out of the pen, returning at dusk. The Hawaiian and English birds, though remaining in distinct flocks within the pon, mixed vory woll outsido it.

Earlier experience with four separato roloasos, of 87 birds in all, on the Island of Hawail, mado with similar rolease pons, has shown that the goese will generally remain in the vicinity of the pen for soveral months. It is plannod to mako annual rolowses of nenes from the same pen in Haleakala Crater for at loast two more years, a total of 100 birds being the aim.

\title{
DAMAGE TO LIVESTOCK FROM RADIOACTIVE FALL-OUT
}

T $\mathbf{N}$ the event of nuclear war, one major problem for civil dofonce authorities would bo the availability and maintonance of food supplies. One aspect of this problem, the effect of fall-out on domestic animals, is considored in a report, entitled, Damage to Livestock from Radioactive Fallout in Event of Nuclear War, prepared by the Subcommittee on Livestock Damage of the Advisory Committee on Civil Defence, National Academy of Sciences-National Research Council, Washington*.

The object of the report is to present estimates of the biological effects of various lovols of radiation exposure. Theso estimates could be used by civil defence planners, whose responsibility would be, first, to feed a population during emorgeney conditions immediatoly following a nuclear attack; secondly, to sustain a population during the subsoquont recovory period; and, thirdly, to ensure an adoquato maintenance of animal populations. No attempt is mado to present maximum permissible levels of exposure, since this concept is considered irrelevant under conditions of national omorgency whore famino and other hazards would far exceed those normally found in peacetime. The report therefore deals mainly with the lethal effects of radiations recoived from oxternal sources or from radioisotopes within, or on, the bodies of animals. On the effect of external radiation, animals invostigated includo cattlo, pigs and poultry, and details are given of the clinical responses of these animals following radiation exposure. Estimates are also presented of the mortality and possible utilization of food animals at different times after brief exposures to various doses of radiation. For mammals, it is estimated that a dose of 350 rads would have only a negligible effect on salvageability; following a dose of 750 rads, most animals could be salvaged during the first three days after exposure, but by tho fourteenth day all animals would bo unfit for use. Fstimates for poultry suggest that these animals are able to withstand slightly higher radiation doses than mammals.

The ingostion of radioisotopes may damage the health of food animals, but may also render them unfit for human use because of the radioactive contamination. The report suggests that contamination should not be significant immediately after a nuclear attack but may become serious if food animals receivo protracted exposure to contamination. This factor might bo moro important for isotopes liko oxsium-137, with a general distribution in the body, than for iodine-131 and strontium 90 which are conceritrated in specific sites. Todine-131 in milk, however, may represent a hazard, particularly to young children. An assessment of tho suitability of contaminated animals for human consumption would roquire knowledge of the amount and distribution of fall-out. The report describes formule which could be used to estimate the probable human hazard on the basis of radioactive contamination of the food intake of animals; it also suggests the usc of certain foods, such as poultry, oggs and some marine animals, which would not be highly contaminated.

On the problem of stock maintenance, the report considers that radiation exposure would not be soriously harmful. Data from a wide variety of adult animals showed no effect on fecundity from radiation exposures of 400 rads. One gap in the data, however, concerns the radiation sensitivity of young animals. Irradiation of pregnant animals produces abnormalities in the foetus, but this would be of minor importance in stock maintenance. Similarly, geno mutations would be unimportant, particularly in view of the high level of selection normal to animal husbandry.

Final chapters in tho report contain recommendations on methods for handling animals which have beon exposed to fall-out and suggestions on areas of investigations in which research is urgently noeded. A series of appendixes presont the basis on which estimates aro made throughout the report and a comprehensive list of references is also included.

C. E. PURDOM

* National Academy of Sciences--National Rescarch Council, Washington, Publication 1078: Damage to Livestork from Radioactive Fallout in Wvent of Nuclear War. Pp. vit93. (Washingtom, 1).C. : National Academy of Science.... Naitonal Rescarch (Council 10633) o dollars.

\section{MUCUS IN INVERTEBRATES}

A GROUP of sciontists intorosted in invostigations on "Mucus in Tnvertebrates" met on August 27, 1963, in Washington, D.C., during tho sixteonth International Congress of Zoology. Tho session was organized for tho Division of Invertebrate Zoology of the American Society of Zoologists by Dr. Sophie Jakowska, Food and Drug Research Jaboratorios, Ine., Maspeth, New York.

Twelve spoakers, reprosonting Austrablia, Brazil, Canada, Donmark, Swoden and the United States, discussed various aspects of slimy secretions of lower animals. The subjects 
discussed by the speakers included: adhering surfaces in Hydra and starfish (Dr. Chaet, American University, Washington, D.C.), mucus-like materials involved in eggshell formation of trematodes (Dr. Clegg, Australian National University, Canberra), mucus of the giant slug, Ariolimax columbianus (Dr. Taylor, Albert Einstein Medical Center, Philadelphia), regeneration of mucusproducing cells in the slug (Dr. Arcadi, Whittier College, California), mucus gland in the octopus (Drs. Gennaro and Lorincz, University of Florida), mucous secretions in ophiuroids (Dr. Fontaine, Victoria University, British Columbia), and in crustaceans (Dr. Dahl, University of Lund, Sweden, and Dr. Steeves, University of Alabama). Mucous substances of protochordates were described by Dr. Norrevang (University of Copenhagen), Dr. Olsson (University of Stockholm) and Dr. Sawaya (University of São Paulo, Brazil). The papers listed on the programme which were not presented included investigations on turbellarians (Dr. Pedersen, University of Copenhagen), on effects of photoperiod on mucus secretions of gastropods (Dr. Segal, San Fernando Valley College, California), and mucopolysaccharides in Molgula (Mrs. Bonnelly deCalventi, University of Santo Domingo, Dominican Republic).

The participants emphasized the great variety of structures in which mucoid substances originate, and their role under normal and experimental conditions. Opinions were expressed that, although there is relatively little information on the chemistry of such materials from invertebrates, it is to be expected that they probably differ in chemical composition from each other, and from the typical salivary secretions of man and mammals which so far have received considerable attention. The ultrastructure of mucus-secreting surfaces was demonstrated by several speakers.

The chairman urged the participants to exploit their familiarity with the widest variety of mucus-secreting organisms as natural working models of normal and abnormal conditions which cannot be examined with equal ease in higher animals. These investigations may shed further light on the physico-chemical properties of pathological mucous secretions, for example, such as those occurring in cystic fibrosis.

During the discussion, a number of speakers remarked on the apparently high concentration of iodides in marine invertebrates which normally secrete copious mucus, as suggested by the characteristic odour. Dr. Anna M. Bidder (University of Cambridge) pointed out the value of excised octopus gut for in vitro investigations on mucus secretion. Dr. Fontaine (Victoria University, British Columbia) mentioned a species of starfish, commonly found along the Pacific Coast, and valuable for the abundant mucus they secrete and collect in a pouch-like structure. Other living systems of interest (for example, hemichordate proboscis) were suggested as models for investigating rheological properties of mucus. The utility of common invertebrates noted for their slimy secretions (slugs, snails) was also stressed.

Since this informal symposium represented only a session of rolated papers during the Congress of Zoology, full manuscripts are not published as part of the Congress Proceedings. The chairman was, therefore, instructed to seek the most suitable means of publication in form of collected papers on mucus in invertebrates. Additional papers and brief communications have been pledged by other authors. The papers have been submitted to the New York Academy of Sciences for publication in the form of Annals of the New York Academy of Sciences. A previous monograph dealing with mucous secretions, including a few papers on mucus in invertebrates, appeared in the Annals in March 1963.

It is hoped that publicizing this meeting and the forthcoming publication will encourage others to work in this important field. A future meeting is planned for 1965 or 1966. Further information can be obtained from Dr. Sophie Jakowska, Food and Drug Research Laboratories, Inc., Maspeth, New York.

\title{
NATURAL OCCURRENCE OF AMINO-ACIDS IN DOLOMITIC LIMESTONES CONTAINING ALGAL GROWTHS
}

\author{
By $D_{R}$. J. S. HARINGTON* \\ Pneumoconiosis Research Unit, South African Council for Scientific and Industrial Research, Johannesburg \\ AND \\ DR. P. D. TOENS \\ Department of Geology, West Rand Consolidated Mines, Ltd., Transvaal
}

\begin{abstract}
$\mathrm{T}$ HE detection of fluorescent oils containing polycyclic aromatic hydrocarbons and amino-acids in crocidolite and amosite asbestos, but not in chrysotile, has been reported by Harington ${ }^{1,2}$ and an organic origin for these materials has been suggested ${ }^{3}$.

This article concerns the detection of amino-acids and hydrocarbons in dolomitic limestones underlying the Pretoria Series in which the crocidolite asbestos horizons are present in the north-western Cape Province, South Africa.

The Dolomite Sories is composed almost entirely of carbonate rocks. It is about $10,000 \mathrm{ft}$. thick in the north-western Cape and 4,000-7,000 ft. in the western Transvaal 4 , and has an estimated age of about 2,000 million yoars ${ }^{5}$.

Recent investigations ${ }^{4}$ have postulated that deposition of the Dolomite Series occurred under warm, shallow and saline conditions. To ollow carbonates to precipitate, the $p \mathrm{H}$ of the water must have been about $8( \pm 0-5)$. Reducing conditions would also have been required for

* Present address: Chester Beatty Research Institute, Institute of Cancer Research, Royal Cancer Hospital, Fulham Road, London, S.W.3.
\end{abstract}

the preservation of organic matter and the formation of pyrite. Various types of algae, of which fossil remains have been found, probably flourished in these quiet conditions, forming a skin over the surface of the sediments.

The siliceous rocks of the overlying Pretoria Series must have been deposited under mildly oxidizing conditions to permit the formation of iron oxides. These conditions would probably not have enabled organic growths to be preserved within the rock, although the detection of amino-acids ${ }^{2}$ does suggest that organisms of some sort were present.

Cyclohexane and ethanolic extractions of three samples of pulverized, primary, dolomitic limestones were carried out by methods described earlier ${ }^{1,2}$. Precautions were taken to avoid contamination of the rocks before and during analysis.

Specimen 1: Dolomitic limestone containing stromatolites (carbon content $0 \cdot 15$ per cent). These algal growths exhibit distinct and rather elaborate branching, and closely resemble the algal heads and domes which are forming in the Great Bahama Bank at the present time ${ }^{6}$. The zones in which these structures are present vary in 